\title{
The rhenium(I)-diselenoether anticancer drug targets ROS, TGF- $\beta 1$, VEGF-A, and IGF-1 in an in vitro experimental model of triple-negative breast cancers
}

\author{
Philippe Collery, ${ }^{1,2, *}$ Vijay Veena ${ }^{3}$ Adhikesavan Harikrishnan, ${ }^{3}$ Didier Desmaele ${ }^{4}$ \\ 1. $\quad *$ Society for the Coordination of Therapeutic Researches, 20220 Algajola, France. \\ philippe.collery@gmail.com, \\ 2 Société de Coordination de Recherches Thérapeutiques, 30, avenue du port, 20220 Algajola, France \\ 3 Biotechnology Department, REVA University, Bangalore 560064, India \\ $4 \quad$ Institut Galien, Université Paris-Saclay, 92296 Châtenay-Malabry, France
}

Summary. The rhenium(I)-diselenoether complex (Re-diSe) is a rhenium tricarbonyl-based drug chelated by a diselenoether ligand. In this work, we compared its inhibitory effects on the hormone-independent MDAMB231cancer line and other different cancer cell lines after an exposure time of $72 \mathrm{~h}$ by MTT assays. The sensitivity of MDA-MB231 was in the same range than the hormone dependent MCF-7 breast cancer, the PC-3 prostate and HT-29 colon cancer cells, while the A549 lung and the HeLa uterine cancer cells were less sensitive. We compared the inhibitory effects of Re-diSe and of its diselenide ligand (di-Se) on MDAMB231 and a normal HEK-293 human embryonic cell line, after $72 \mathrm{~h}$ and $120 \mathrm{~h}$ of exposure. The cytotoxicity was also studied by flow cytometry using ethidium bromide assays, as well as the effects on the ROS production by DFCA-test, while the levels of TGF- $\beta 1$, VEGF-A, IGF-1 were addressed by ELISA tests. The dose required to inhibit 50\% of the proliferation (IC50) ofMDAMB231 breast cancer cells decreased with the time of exposure to $120 \mathrm{~h}$, while the free ligand (di-Se) was found poorly active, demonstrating the important role of Re in this RediSe combination. The cytotoxic effects of Re-diSe were highly selective for cancer cells, with a significant increase of the number of dead cancer cells at $5 \mu \mathrm{M}$ for an exposure time of $120 \mathrm{~h}$, while normal cells were not affected. A remarkable and significant decrease of the production of ROS together with a decrease of VEGF-A, TGF- $\beta 1$, and IGF-1 by the cancer cells were also observed when cancer cells were exposed to Re-diSe.

Key-words. Rhenium(I)-diselenoether . Rhenium . Selenium . Cancer . Selectivity . ROS . VEGF . IGF . TGF 


\section{Introduction}

Metastatic triple-negative breast cancer $(\mathrm{mTNBC})$ is still a disease with a poor prognosis. In a randomized clinical trial comparing two lines of chemotherapy in mTNBC, without prior chemotherapy, the investigatorassessed progression free survival (PFS) was only of 8.3 months in the bestg best arm and 5.5 months in the other one [1]. The overall survivals (OS) were respectively of 16.8 and 12.1 months. In a single arm phase II clinical trial, with cabozantinib, a multikinase inhibitor, the median PFS was of only 2 months in the 35 patients enrolled in this study. In a phase 3 randomizedclinical trial (IMpassion130), presented at the European Scientific Medical Oncology (ESMO) conference 2018, it has been shown that the combination of atezolizumab, an inhibitor of the immune programmed death ligand 1 (PD-L1) and nab-paclitaxel, a chemotherapeutic drug, significantly improved the PFS, versus nabpaclitaxel alone [2]. However, the median PFS was 7.2 months and the OS 21.3 months in the best arm, with the inhibitor of a check-point immunity, and adverse events leading to the discontinuation of the treatment were observed in $15.9 \%$ of the patients who received atezolizumab plus nabpaclitaxel. In the PD-L1-positive subgroup, the median PFS was 7.5 months and the median OS 25 months. Comparable results were obtained in a phase II study published in 2016, with a PFS of 7.6 months and a median OS of 19.2 months in a weekly paclitaxel, capecitabine and bevacizumab regimen [3]. These trials confirm the well-known bad prognostic of this aggressive disease. A new rhenium-diselenium complex is active in amodel of triple negative breast cancer. Few years ago it has been reported a new rhenium $(\operatorname{Re})$ complex, $\operatorname{Re}(\mathrm{I})$ diselenoether that we shall abbreviate Re-diSe, featuring a tricarbonyl $\operatorname{Re}(\mathrm{I})$ metal core chelated by a bidentate3,7-diselenanonanedioate ligand in which the two selenium (Se) atoms secure a tight complexation of the Re, while the sodium carboxylate groups confer water solubility [4]. Re-diSe was shown to exhibit significant cytotoxicity against hormone-sensitive MCF-7 and hormone-independent MDA-MB231 breast cancer cell lines. The uptake and efflux of Re in malignant cells exposed to Re-diSe have been reported, together with evidence of the incorporation of $\mathrm{Re}$ into the nucleus [5]. Tissue distribution of $\mathrm{Re}$ and Se after oral administration of Re-diSe to mice has also been reported. More remarkably, it was shown that Re-diSe compound had anticancer effects on an experimental model of triple negative breast cancer (TNBC) with MDAMB231 transplanted tumour-bearing mice $[6,7]$. In order to have a good therapeutic index an anticancer drug should have to kill the cancer cells while preserving the normal cells. It is never completely possible, explaining in part the well-known side effects observed after chemotherapy, but also with targeted therapies [8] and even with new immunotherapeutic agents $[9,10]$. There is still a need to find new anticancer drugs or new strategies of treatment for improving the selectivity of the treatments on cancer cells versus normal cells. Our aim was to 
determine if this new drug will have a high selectivity for the cancer cells. In this perspective, MDAMB231 cancer cells were chosen as an in vitro experimental model. We investigated the selective inhibitory and cytotoxic effects of Re-diSe on these MDA-MB231 cancer cell lines in respect to various cancer cell lines and on a normal human embryonic HEK-293 cell line. We also compared the inhibitory effects of the Re-diSe compound and of its diselenide ligand (di-Se) on MDA-MB231 and HEK-293 as a function of exposure time, to better determine the role of Re in this combination. We also aimed to define the role of the RediSe drug on the production of Reactive Oxygen Species (ROS) as the importance of the oxidative stress in breast cancers has been highlighted [11]. It was also showed in four isogenic triple-negative breast cancer cell lines that the increase in the metastatic potential was correlated with an increase of the redox potential [12]. Bahhnassy and al. assayed TGF- $\beta 1$, IGF-1 and VEGF-A in patients with mTNBC and proved that they may be considered as good markers of TNBC [13]. We therefore also report herein the effect of the Re-diSe drug on the production of TGF$\beta 1$, IGF-1 and VEGF-A by the MDA-MB231 cancer cells.

\section{Material and methods}

\section{Synthesis of the Re-diSe compound and of its di-Se ligand}

The Re-diSe complex and the corresponding diselenide ligand depicted in Fig. 1 were prepared according to the procedure of synthesis first described by Kermagoret and al. [4] and further improved [6].

\section{Cell lines and reagents}

Cell lines were purchased from National Centre for Cell Science (NCCS), Pune, India and maintained in the $\mathrm{CO}_{2}$ incubator as per the standard protocol. Dimethyl sulfoxide (DMSO), Dulbecco's modified eagle medium (DMEM), fetal bovine serum (FBS), Rosewell park memorial institute (RPMI), penicillin, streptomycin, amphotericin B, 3-[4, 5-dimethylthiazol- 2-yl]-2,5-diphenyl tetrazolium bromide (MTT), ethidium bromide (EB) were purchased from Sigma Aldrich, USA. ELISA kits for the biomarkers were purchased from ELabscience, UK.

\section{Assays of the inhibitory effects}

The inhibitory effects were studied by the (3-(4,5-dimethylthiazol-2-yl)-2,5-diphenyltetrazolium bromide) tetrazolium reduction assay (MTT test). They were first assayed in different cancer cell lines and one normal human embryonic kidney cell line HEK-293. The cancer cell lines were derived from prostate cancer (PC-3), hormone-dependent breast cancer (MCF-7), hormone-independent breast cancer (MDAMB231), colon cancer (HT-29), cervical uterine cancer (HeLa) and non-small cell lung cancer (A-549): We then selected the MDA- 
MB231 cells to investigate theeffects of 2 different times of exposure of the drug to the cells, $72 \mathrm{~h}$ versus $120 \mathrm{~h}$.

We also compared the effects of the RediSe compound versus its di-Se ligand. The dose inhibiting $50 \%$ of the proliferation of the cells (IC50) was defined.

\section{Assays of the cytotoxic effects}

The cell deaths were measured by ethidium bromide uptake tests on 30.000 drug treated cells from $1 \times 106$ cells. The cells were analyzed by flow cytometry to assess the ethidium bromide stained dead cells.

\section{Assays of the ROS production}

The production of ROS was measured by fluorimetric quantification of fluorescent 2,7-dicholorofluorescein (DCF) formed in presence of ROS by using cell permeable non-fluorescent, 2,7-dichlorofluorescein diacetate (DCF-DA). After treatment, the cells were trypsinized, pelleted, washed twice with PBS and exposed to DCFDA $(10 \mu \mathrm{M})$ in DMEM medium for $45 \mathrm{~min}$ at $37^{\circ} \mathrm{C}$. After incubation, the cells were analyzed using 96 -well multimode reader excited at $480 \mathrm{~nm}$ and emission was recorded at $540 \mathrm{~nm}$.

\section{Assays of the biomarkers}

TGF- $\beta 1$, IGF-1 and VEGF-Awere assayed by ELISA tests in the culture medium, reflecting their release by the cells, but not directly in the cells where the changes are too much rapid to be detected by these methods.

\section{Statistical analysis}

Results were expressed as mean \pm SD of triplicate experiments. The statistical analysis was performed using the SPSS software. The comparison of the efficacy of the RediSe drug for inhibiting cancer and normal cell lines was performed by one-way ANOVA test. Effects of doses in the further experiments were analysed using the Mann-Whitney U tests. Results were considered statistically significant with $\mathrm{p}<0.05$ at $95 \%$ confidence levels by two tailed tests.

\section{Results}

\section{Inhibitory effects}

Effects of the Re-diSe compound on different cancer cell lines and on the normal HEK-293 cell line

After a 72 h-exposure time, there was a clear dose-response effect depending on the type of the cancer cells, as represented in Fig. 2 and Table 1. Statistically significant inhibitory effects were observed for the MCF-7 and MDA-MB231 breast cancer cell lines, as well as for the prostate and colon cancer cell lines with doses $\geq 25 \mu \mathrm{M}$ versus the normal cell line with $\mathrm{IC}_{50}$ doses of respectively 126 to $133 \mu \mathrm{M}$. Remarkably, the inhibition of the 
normal cells was less than $25 \%$ even with the highest dose of $200 \mu \mathrm{M}$ Re-diSe drug. The IC50 was not reached for the normal cells.

Inhibitory effects of Re-diSe and di-Se after 2 different exposure times Effects of Re-diSe

\section{Effects of Re-diSe}

After $72 \mathrm{~h}$ exposure, the IC50 of the Re-diSe drug was $58.74 \pm 3.43 \mu \mathrm{M}$ in MDA-MB231 cancer cells versus $148.7 \pm 10.67 \mu \mathrm{M}$ in normal HEK-293 cells, in the conditions of this experiment. A dose of $50 \mu \mathrm{M}$ of the RediSe drug inhibited $50 \%$ of the malignant cells, but less than $20 \%$ of the normal cells (Fig. 3a). The decreased cell proliferation was statistically significant with doses $\geq 50 \mu \mathrm{M}$ Re-diSe in cancer cells and with doses $\geq 100 \mu \mathrm{M}$ in normal cells. The increase of the time of exposure to $120 \mathrm{~h}$ induced a decrease of the IC50 of the Re-diSe complex to $18.83 \pm 0.98 \mu \mathrm{M}$ for the cancer cells, but also in normal cells, with an IC50 of $109.90 \pm 4.34 \mu \mathrm{M}$. A dose of $25 \mu \mathrm{M}$ of the RediSe drug inhibited more than $60 \%$ of the malignant cells, but less than $20 \%$ of the normal cells (Fig. 3b). The decreased cell proliferation was statistically significant with doses $\geq 25 \mu \mathrm{M}$ Re-diSe in cancer cells and with doses $\geq 100 \mu \mathrm{M}$ in normal cells.

\section{Effects of di-Se}

After $72 \mathrm{~h}$ exposure, the IC50 of the di-Se ligand was more than twofold higher in cancer cells $(153.3 \pm 3.78 \mu \mathrm{M})$ than for the Re-diSe complex, and not reached in normal cells (Fig. 3c). The decreased cell proliferation was statistically significant with doses $\geq 100 \mu \mathrm{M}$ diSe in cancer cells and with doses of $200 \mu \mathrm{M}$ in normal cells.

After $120 \mathrm{~h}$ exposure, the IC50 of the di-Se ligand was decreased to $68.4 \pm 3.18 \mu \mathrm{M}$ on cancer cells, but a cytotoxicity appeared on normal cells with an IC50 of $165.29 \pm 12.28 \mu \mathrm{M}$ (Fig. 3d). The decreased cell proliferation was again statistically significant with doses $\geq 100 \mu \mathrm{M}$ di-Se in cancer cells and with doses of 200 $\mu \mathrm{M}$ in normal cells. The di-Se compound appears to be less active than the whole Re-diSe complex, with a worse selective index.

Table 1 Inhibitory-effects of the Re-diSe compound on different cancer cell lines and one normal human embryonic kidney cell line after an exposure time of $72 \mathrm{~h}$ 


\begin{tabular}{|c|c|c|c|c|c|c|c|}
\hline $\begin{array}{l}\text { Dose } \\
(\mu \mathrm{M})\end{array}$ & HEK-293 & MDAMB231 & MCF-7 & PC-3 & HT-29 & $\mathrm{HeLa}$ & A-549 \\
\hline 0 & $00.75 \pm 0.12$ & $5.00 \pm 0.98$ & $5.60 \pm 0.94$ & $3.10 \pm 0.73$ & $5.5 \pm 0.92$ & $1.25 \pm 0.06$ & $2.40 \pm 0.33$ \\
\hline 5 & $1.60 \pm 0.53$ & $8.82 \pm 0.47$ & $9.82 \pm 0.92$ & $6.70 \pm 0.45$ & $10.81 \pm 1.74$ & $2.55 \pm 0.52$ & $4.31 \pm 0.63$ \\
\hline 10 & $2.85 \pm 0.67$ & $17.77 \pm 0.69$ & $17.77 \pm 1.28$ & $12.85 \pm 1.50$ & $16.81 \pm 1.98$ & $4.30 \pm 1.34$ & $7.72 \pm 0.96$ \\
\hline 25 & $6.90 \pm 0.84$ & $27.54 \pm 1.38 *$ & $36.48 \pm 2.53 *$ & $28.86 \pm 1.23 *$ & $29.86 \pm 2.82^{*}$ & $8.05 \pm 2.23$ & $14.81 \pm 0.74$ \\
\hline 50 & $11.28 \pm 0.79$ & $50.77 \pm 1.53^{*}$ & $50.37 \pm 2.62 *$ & $53.27 \pm 1.27^{*}$ & $56.72 \pm 2.26^{*}$ & $15.32 \pm 2.87$ & $24.71 \pm 0.67$ \\
\hline 100 & $16.89 \pm 0.91$ & $70.40 \pm 2.42^{*}$ & $66.92 \pm 3.42 *$ & $61.31 \pm 2.98^{*}$ & $66.26 \pm 2.83^{*}$ & $47.17 \pm 2.89$ & $47.77 \pm 1.76$ \\
\hline 200 & $23.63 \pm 1.68$ & $84.81 \pm 2.94 *$ & $71.93 \pm 2.57 *$ & $73.31 \pm 3.23^{*}$ & $80.26 \pm 2.89 *$ & $60.32 \pm 3.89$ & $60.31 \pm 4.40$ \\
\hline $\mathrm{IC}_{50}$ & Not reach & $48.51 \pm 2.76$ & $51.36 \pm 2.95$ & $59.44 \pm 3.83$ & $47.52 \pm 0.89$ & $126.40 \pm 2.76$ & $133.20 \pm 4.32$ \\
\hline
\end{tabular}

Results are expressed as the $\%$ of inhibition (mean \pm SD) of the cells. IC50: concentration inhibiting the growth of $50 \%$ of the cells *statistically different $(p<0.05)$ from the normal HEK-293 cell line

\section{Cytotoxic effects}

The inhibition of the cell growth does not mean that the cells are killed. The exact number of cell deaths was estimated through ethidium bromide staining using flow cytometer cell count. Results are represented in Fig. 4. They express the number of dead cells among 30.000 cells analysed by flow cytometry in triplicate of four independent experiments. There was a dramatic increase of the number of dead cells from $5790 \pm 67$ to $17,678 \pm$ 178 when increasing the dose of RediSe from 5 to $25 \mu$ MinMDA-MB231 cells versus only from $2520 \pm 78$ to $3203 \pm 89$ in normal cells. Deaths of cancer cells were statistically significant even with the low doses of $5 \mu \mathrm{M}$, but only with the highest dose of $200 \mu \mathrm{M}$ in normal cells. A great selectivity of the Re-diSe drug has been shown in this experiment for the cancer cells, and moreover a great efficacy. The curve was biphasic with a high cytotoxic effect observed when increasing the doses until $25 \mu \mathrm{M}$, but less important with higher doses. Nevertheless, at the highest dose of $200 \mu \mathrm{M}$, nearly all the cancer cells were killed $(28,789 \pm 338$ dead cancer cells). 


\section{Effects on the ROS production}

One of the possible mechanism of action of the Re-diSe complex is to modulate the production of ROS. We observed a rapid dose-dependent decrease of the ROS production in the cancer cells, as showed in Fig. 5, with an aspect of biphasic curve. The ROS were statistically significantly decreased with all doses, even with the lowest dose of $5 \mu \mathrm{M}$. On the other hand, the levels of ROS were very low at the basal levels in normal cells, about 1500 arbitrary units (a.u), by comparison with the levels observed in the cancer cells (about 2500 a.u), and were only statistically significantly decreased at the highest dose of $200 \mu \mathrm{M}$ Re-diSe.

\section{Effects on VEGF-A, TGF- $\beta 1$ and IGF-1}

The concentrations of the markers were determined in the medium before using it for the cell experiments. They were of $78 \pm 12 \mathrm{ng} / \mathrm{ml}$ for TGF- $\beta 1,122 \pm 15 \mathrm{ng} / \mathrm{ml}$ for VEGF-A and $85 \pm 11 \mathrm{pg} / \mathrm{ml}$ for IGF-1. After an exposure time of $120 \mathrm{~h}$ of MDA-MB231 cancer cells, we observed that the levels of the three biomarkers were very high in the medium in the absence of treatment and decreased under the influence of the Re-diSe drug with a dose-dependent effect, as represented in Figs. 6, 7 and 8. In the case of HEK-293 cells, the levels were nonsignificantly decreased when the Re-diSe drug was added.

\section{VEGF-A}

The levels of VEGFA (Fig. 6) decreased from $698 \pm 11 \mathrm{ng} / \mathrm{ml}$ before treatment to $529 \pm 17 \mathrm{ng} / \mathrm{ml}$ with the dose of $25 \mu \mathrm{M}$ Re-diSe in cancer cells and from $98 \pm 9$ to $97 \pm 13 \mathrm{ng} / \mathrm{ml}$ in normal cells. At the highest dose of 200 $\mu \mathrm{M}$, the levels of VEGF-A were $278 \pm 17$ in cancer cells and $87 \pm 8$ in normal cells. Results were statistically significant with doses $\geq 5 \mu \mathrm{M}$ in the medium of cancer cells, but no significant decrease was observed in the medium of the normal cells. The levels of VEGF-A remained stable with the normal cells, but a biphasic curve was observed with the cancer cells, with a sharp decrease from 5 to $25 \mu \mathrm{M}$ Re-diSe.

\section{TGF- $\beta 1$}

The levels of TGF- $\beta 1$ (Fig. 7) decreased from $892 \pm 8 \mathrm{ng} / \mathrm{ml}$ before treatment to $768 \pm 16 \mathrm{ng} / \mathrm{ml}$ with the dose of $25 \mu \mathrm{M}$ Re-diSe in cancer cells and from $121 \pm 13$ to $114 \pm 11 \mathrm{ng} / \mathrm{ml}$ in normal cells. At the highest dose of 200 $\mu \mathrm{M}$, the levels of TGF- $\beta 1$ were $479 \pm 42$ in cancer cells and $104 \pm 14$ in normal cells. The levels of TGF- $\beta 1$ remained stable in the normal cells, but a biphasic curve was observed in cancer cells, with a sharp decrease until 
$100 \mu \mathrm{M}$ Re-diSe. Results were significant with doses $\geq 5 \mu \mathrm{M}$ Re-diSe with the cancer cells but the decrease was not significant for the normal cells, even with the highest dose.

\section{IGF-1}

The levels of IGF-1 (Fig. 8) decreased from $414 \pm 23 \mathrm{ng} / \mathrm{ml}$ before treatment to $269 \pm 27 \mathrm{pg} / \mathrm{ml}$ with the dose of $25 \mu \mathrm{M}$ Re-diSe in cancer cells and from $84 \pm 42$ to $77 \pm 63 \mathrm{pg} / \mathrm{ml}$ in normal cells. At the highest dose of $200 \mu \mathrm{M}$, the levels of IGF-1 we cells, but a biphasic curve was observed in cancer cells, with a sharp decrease from 5 to $25 \mu \mathrm{M}$ Re-diSe. Results were significant with doses $\geq 5 \mu \mathrm{M}$ Re-diSe with the cancer cells but the decrease was not significant for the normal cells, even with the highest dose.

\section{Discussion}

\section{The inhibitory effects are dose-and time-dependent}

We demonstrated that the Re-diSe and the di-Se compounds induced selective inhibitory effects on MDAMB231 cancer cells by comparison with normal HEK-293 cells. MTT tests have a lower accuracy than the assay of dead cells by ethidium bromide staining in selected cells by flow cytometry. These MTT tests nevertheless gave the possibility to show the importance of the time of exposure to inhibit the cell growth. The inhibitory effects were dose-and time-dependent, more pronounced for Re-diSe than for its ligand. The efficacy increasing with the time of exposure suggests the use of repeated administrations of the drugs, with low doses, to get an even more favorable therapeutic index. Continuous administrations of the Re-diSe drug have already been tested in mice. A significant anticancer activity was observed at the dose of $10 \mathrm{mg} / \mathrm{kg} / 24 \mathrm{~h}$ Re-diSe in MDA-MB231 transplanted tumor mice as a daily administration, for 4 weeks, either orally [6] or intraperitoneally (I.P) [7]. The $10 \mathrm{mg} / \mathrm{kg} / 24 \mathrm{~h}$ dose was clinically safe in the both cases. The I.P injection of $40 \mathrm{mg} / \mathrm{kg} / 24 \mathrm{~h}$ did not significantly reduce the tumor growth by comparison with the dose of $10 \mathrm{mg} / \mathrm{kg} / 24 \mathrm{~h}$, but induced a letal toxicity of $10 \%$ (LD10) and higher doses than $40 \mathrm{mg} / \mathrm{kg} / 24 \mathrm{~h}$ were not well tolerated. A metronomic schedule of treatment was proposed and lower doses than $10 \mathrm{mg} / \mathrm{kg} / 24 \mathrm{~h}$, with a longer period of administration, should also be tested.

\section{The cytotoxic effects are highly selective for the cancer cells}


Cytotoxic effects of the Re-diSe drug were demonstrated with doses $\geq 5 \mu \mathrm{M}$ for $120 \mathrm{~h}$, while the normal cells were only affected with the highest dose of $200 \mu \mathrm{M}$. The great selectivity of the Re-diSe for killing cancer cells and not the normal cells appears to be very promising for its therapeutical use in mTNBC. The selectivity of Re metal-based compounds for cancer has already been shown, particularly with $\operatorname{Re}(\mathrm{I})$ tricarbonyl complexes in which a $f a c-\operatorname{Re}(\mathrm{CO})_{3}$ moiety is bound to various ligands including salicylaldehyde semicarbazones [14] or pyridyltriazole ligands [15], but also for dimetallic complexes with two $f a c-\operatorname{Re}(\mathrm{CO})_{3}$ units bridged together [16]. The selective cytotoxicity has also been shown for hypoxia cells [17]. For example, $\operatorname{Re}(\mathrm{I})$ metalla-crown ethers were tested on many cancer cell types and showed selective cytotoxic activities by comparison with peripheral blood mononuclear cells (PBMCs). Doses up to $50 \mu \mathrm{M}$ for $48 \mathrm{~h}$ induced inhibitory effects less than $20 \%$ in PBMCs but more than $50 \%$ in all cancer cells for an exposure time of $48 \mathrm{~h}$ [18]. However, $\operatorname{Re}(\mathrm{CO})_{3}$ pentylcarbanato complexes have been studied by Parson and al. [19] on hormone-independent breast cancer cell lines (MDA-MB-468) and compared to normal kidney cells, and a low selectivity index was observed since a $50 \%$ growth inhibitory concentration ( $\mathrm{IC}_{50}$ ) of the cancer cells was reached with doses of 2 to $5 \mu \mathrm{M}$, when normal cells were inhibited with an $\mathrm{IC}_{50}$ ranging from 1 to $5 \mu \mathrm{M}$. The cytotoxicity of Re acetylsalicylate compounds (RAC) has been studied by Banerjee and al. in malignant astrocytoma cells versus normal astrocytes, at the dose of $2 \mu \mathrm{M}$ [20]. For the best compound, RAC6, the cell death was nearly $70 \%$ in cancer cells and nearly $20 \%$ in normal cells. Beside metals, trace elements such as Se may have an anticancer activity, and selective inhibitory effects of Se-containing compounds have been shown, in particular in the case of diselenide structures [21, 22].

\section{ROS production}

The main anticancer mechanism of action of Re-diSe could be due to its effect on ROS, via changes in all major signaling pathways and on the cancer immunosuppression. It could contribute to restore the reduced dithiol status of proteins by the reduction of disulfide bonds. Cytotoxic agents usually increase the oxidative stress and by this way induce side toxic effects. There is an excess of production of ROS in cancer cells, depending on the type of cancer, the histological subtypes, the stage of the disease [23]. TNBC cells have a pro-oxidant status with an excess of production of ROS and moreover the redox ratio increased with increasing metastatic potential [12]. ROS and Reactive Nitrogen Species (RNS) act as redox messengers of transmembrane receptors and trigger the activation or inhibition of signal transduction kinases/phosphatases, such as the family members of protein tyrosine kinases and protein tyrosine phosphatases as reviewed by Gao X and Schottker B [24]. These reactions activate downstream signaling pathways including protein kinase of the MAPK cascade, PI3K and 
PKC. Moreover, the kinases and phosphatases regulate the phosphorylation status of transcription factors including APE1/Ref-1, HIF-1 $\alpha$, AP-1, Nrf2, NF-кB, p53, FOXO, STAT, and $\beta$-catenin. Finally, ROS and Reactive Nitrogen Species (RNS) act as second messengers to favour the progression of the cancer disease [23]. ROS also play an important role as signaling messengers in immune system and modulating the level of ROS may be important to prolong survival of $\mathrm{T}$ cells and enhance their antitumor function [25]. Myeloid derived suppressor cells (MDSCs) are immunosuppressive, immature myeloid cells often arising in oxidative-stress prone environments such as in tumors or during inflammation and infection [26]. ROS not only activate antioxidative pathways but also induce transcriptional programs that regulate the fate and function of MDSCs. Targeting redox-regulation of MDSCs can represent a new approach to cancer therapy. Phosphatase and tensin homologs deleted on chromosome 10 (PTEN) are tumor suppressors that play important roles in cell growth, proliferation, and cell survival by negative regulation of phosphoinositol-3-kinase/protein kinase B signaling. Oxidization of PTEN will result in a disulfide bond between cysteine residues (Cys124) and (Cys71) resulting in inactivation of PTEN phosphatase activity [27]. Physiological PTEN oxidation is a reversible process. Oxidized PTEN is reversibly converted back to the reduced form by the intracellular reducing systems, such as thioredoxin (Trx) and glutaredoxin (Grx) systems. Depletion of Trx markedly reduces the rate of PTEN reduction in cells. The cysteine residues can be further oxidized into irreversible sulfinic and sulfonic acids upon ongoing exposure to oxidants, which cannot be reduced by cellular redox systems or artificial reductants. At the reversible step, Re-diSe could help the anti-oxidant system to reduce PTEN and reactivates its role as suppressor gene. Protein tyrosine phosphatases (PTPs) are regulated through reversible oxidation of the active-site cysteine, for example by peroxidized lipids [28]. Signaling through receptor tyrosine kinases (RTKs), such as the PDGF $\beta$-receptor, are subjected to negative control by protein tyrosine phosphatases. Inhibiting PTPs will thereby increase RTK signaling. Reducing PTPs by Re-diSe could decrease the RTK signaling. In fact, it has already been shown that Re and Se have redox properties that may be linked to their anticancer activity. For example, $\operatorname{Re}(\mathrm{I})$ tricarbonyl complexes, bearing bidentate hydrazine were able to induce a cell death via an apoptotic mechanism while a decrease in intracellular levels of ROS was observed [29]. A $\operatorname{Re}(\mathrm{I})$ tricarbonyl complex of 21,23diselenaporphyrin was synthesized in which $\operatorname{Re}(\mathrm{I})$ ion binds to $\mathrm{Se} / \mathrm{S}$ atoms, with redox properties [30]. The intercalation of a Re compound in polynucleotides has been observed, and free radicals exhibited more affinity for the intercalated complexes than for the bases of the polynucleotides with a redox reaction from $\operatorname{Re}(\mathrm{I})$ to a $\operatorname{Re}(\mathrm{II})$ species [31]. A Re- Platinum $(\mathrm{Pt})$ compound provided excellent anticancer properties with anti-oxidant effects [32]. It is less simple with Se compounds, as they may have dual roles, either anti-oxidant or pro-oxidant, 
either pro-angiogenic or antiangiogenic [23]. It is usually as pro-oxidant that Se compounds showed an anticancer activity, even though the cancer cells have a pro-oxidant status [23]. Nevertheless, a Se-Pt compound showed a high selectivity for cancer cells with anticancer properties related to the production of reactive oxygen species (ROS) [33]. In our study, we demonstrated that the inhibitory and cytotoxic effects of the Re-diSe were correlated with a significant decrease of the production of ROS by the cancer cells. The redox properties of this Re-diSe compound could be used to try to normalize the production of the radical species by the cancer cells. The objective of normalizing the redox status of cancer cells has already been proposed for Se-based drugs [23], but due to the greater effectiveness of Re-diSe than di-Se to inhibit the growth of the malignant cells, this goal could be perhaps more easily achieved with the Re-diSe complex than with any Se containing drugs. The levels of ROS in HEK-293 normal cells do not reflect those that could be observed in the peritumoral breast tissue in human patients, or in their blood. In this experiment, the levels of ROS in cancer cells did not decrease until the levels observed in HEK-293 cells, but it is an in vitro experiment with cells in culture. There is a great need to test Re-diSe in animal models with assays of ROS in the tumor, the peri-tumoral tissue and in the blood and to note if it will be possible to observe a normalization of the markers of the oxidative stress in all tissues.

\section{Effects of the Re-diSe drug on the TGF-ß1, VEGF-A and IGF-1 levels}

The significant decrease of TGF- $\beta 1$, VEGF-A and IGF-1 in the culture medium may reflect the anticancer activity of the Re-diSe drug, and could be a consequence of the ROS decreased. Doses of Re-diSe $\geq 5 \mu \mathrm{M}$ for $120 \mathrm{~h}$ significantly and selectively reduced the production of VEGF-A, IGF-1, and TGF- $\beta 1$, but with also a dose-dependent effect.

\section{VEGF-A}

High VEGF-A expression is associated with worse disease-free and distant metastasis-free survival in TNBC, and many researches have been performed on antiangiogenic drugs. For example, it has been shown that Regorafenib, a multi-receptor tyrosine kinase (RTK) inhibitor induced significant TNBC anti-migratory effects, in association with downregulation of VEGF-A [34]. The Vascular Epithelial Growth Factor (VEGF-A) is a good marker of angiogenesis, and plasma VEGF levels were $154.7 \pm 124.7$ in 103 breast cancer patients versus $22.7 \pm 18.3$ in 40 patients without cancer [35]. On the other hand, it is known that Se compounds may have antiangiogenic properties. A decrease of VEGF and PDL1 was reported with methylseleninic (MSA) acid that 
increased natural killer (NK) cell mediated lysis of an ovarian cancer cell line and enhanced the cytolytic activity of immune T cells, without toxicity for the immune cells at doses providing cytotoxic effects for the cancer cells [36]. There is a correlation between the oxidative stress and angiogenesis [23] and it may be by its effect on the ROS production that the Re-diSe decreased the levels of VEGF in the medium of culture of the cancer cells.

\section{TGF- $\beta 1$}

Elevated plasma TGF- $\beta 1$ have been correlated with decreased survival in metastatic breast cancer patients [37]. The mean values were of $1.30 \mathrm{ng} / \mathrm{ml}$ in 37 patients without cancer, $0.94 \mathrm{ng} / \mathrm{ml}$ in 10 patients with early breast cancers (stages I and II) and $2.34 \mathrm{ng} / \mathrm{ml}$ in 43 late stages (III and IV). The survival was significantly reduced in patients with plasma TGF- $\beta 1$ higher than $3 \mathrm{ng} / \mathrm{ml}$ by comparison with lower values and plasma TGF- $\beta 1$ could be considered as good tumor markers in breast cancer patients. In early stages of breast cancer, TGF- $\beta 1$ inhibits epithelial cell line progression and promotes apoptosis, showing tumor suppressive effects, while in late stages of breast cancer, this cytokine is linked with increased tumor progression, higher cell motility, cancer invasiveness, metastasis and promotion of epithelial to mesenchymal transition (EMT) [38]. The relationship between TGF- $\beta$ expression and invasion has been observed in TNBC cells [39] and inhibiting the TGF- $\beta$ signaling pathway is considered a promising therapeutic strategy for treating TNBC. The therapeutic effects of TGF- $\beta$ inhibitors could be due to the inhibition of angiogenesis and the reversal of the invasive/ metastatic phenotypes of the tumor cells [40]. The inhibition of expression of TGF- $\beta 1$ in human PC-3 prostate cancer cells has already been described with a Se salt [41]. As a result of the decrease of the production of TGF- $\beta 1$ by the Re-diSe, a reversal of the malignant phenotype may be expected. There is also a correlation between oxidative stress and TGF- $\beta 1$ as observed in the blood of patients with melanoma [42], and it may be by its effect on the ROS production that the Re-diSe decreased the levels of TGF- $\beta 1$ in the medium of culture of the cancer cells.

\section{IGF1}

The insulin-like growth factor type 1 receptor (IGF-1R) is a receptor tyrosine kinase, synthesized as a single chain $\alpha-\beta$ pro-receptor and in its mature, functional form, it consists of two identical extra cellular $\alpha$-subunits and two identical $\beta$-subunits, all linked by disulfide bridges [43]. Anti-oxidants may reduce disulfide bridges and by this way, the anti-oxidant Re-diSe compound could affect the binding of IGF-1 to its receptor. Around 99\% of IGF1 circulates bound to IGF binding proteins in the blood, with most bound to IGF binding protein 3 (IGFBP3) and less than 1\% of IGF1 circulates unbound. Circulating IGF1 was found positively associated with 
breast-cancer risk, while variations in IGFBP3 concentrations by breast-cancer risk factors was less pronounced than that for IGF1 [44]. Assays of IGF-1 could therefore be better markers of breast cancers than IGFBP3. It has been found that plasma median concentrations of IGF-1 were significantly higher in primary breast cancers (26 $\mathrm{ng} / \mathrm{ml}$ ) than in controls $(20 \mathrm{ng} / \mathrm{ml})$ [45]. The IGF-1/ IGF-IR pathway is involved in the migration and invasion of MDA-MB231 cancer cells, and anti-IGF-IR strategies effectively reduced metastatic potential of different ERnegative cell lines, suggesting a role of this receptor in late stages of the disease [46]. For example, miR-135a promoted cell apoptosis and inhibits cell proliferation, migration, invasion and tumor angiogenesis by targeting IGF-1 gene through the IGF-1/PI3K/Akt signaling pathway [47]. IGF-1 is a peptide which stimulates protein synthesis by upregulating phosphorylation of PI3K, Akt, and mTOR [48], but it also activates the mitogen activated protein kinase kinase (MEK)-extracellular signal-regulated kinase (ERK) [49]. On the other hand, it has also been shown that Se could significantly affect IGF-IR expression, with a dual role, either decreasing or increasing its expression [50]. In our study, the Re-diSe drug decreased the levels of IGF-1. Decreasing the levels of IGF-1 by the Re-diSe compound could inactive the very important PI3K/Akt/mTOR and MEK/ERK pathways, involved in cancer progression.

\section{Conclusion}

In conclusion, the main effect observed in this study could be the significant decrease of the ROS production by the cancer cells with low doses of Re-diSe, for $120 \mathrm{~h}$, with great inhibitory and cytotoxic selective effects for the MDA-MB231 cancer cells, respecting the normal HEK-293 cells. We showed that the Re-diSe complex was more effective than its di-Se ligand, suggesting that Re plays a critical role in the anticancer activity. Due to this ability of the Re-diSe drug to decrease the production of ROS, it could be classified as an anti-oxidant agent. Moreover, doses of $5 \mu \mathrm{M}$ Re-diSe for $120 \mathrm{~h}$ significantly decreased the levels of TGF- $\beta 1$, VEGF-A and IGF-1 in the medium of culture of the cancer cells and not in the medium of the normal HEK-293 cells. Therefore, the Re-diSe drug may be considered as a targeted anticancer therapy. The main mechanism of action of Re-diSe could be its anti-oxidant effect, which could be responsible of the decrease of the markers of major signaling pathways. However, it has to be noted another effect of Re-diSe which is its ability to bind the Re atom to one or two guanine bases of DNA, like cisplatin and other Re-based complexes [6]. The mitochondrial DNA is greatly involved in the ROS and RNS productions and the binding of Re with the DNA bases could be related to its effect on reactive species. Experiments will be required to elucidate the consequences of the binding of Re to the DNA bases and its eventual relationship with the effects of the RediSe drug on the ROS production. Finally, 
ROS, TGF- $\beta 1$, VEGF-A and IGF-1 may be useful markers to monitor the treatment, with the possibility to be assayed in the plasma of cancer patients. Further experimental studies in tumour-bearing animals should be performed with syngeneic models of mTNBC to give the possibility to investigate the immune system, and to determine if the decreased plasma or anticancer efficacy.

\section{Compliance with ethical standards}

Conflict of interest Philippe Collery declares that he is owner of a patent on "Rhenium complexes and their pharmaceutical use".

Vijay Veena, Adhikesavan Harikrishnan and Didier Desmaele declare that they have no conflict of interest.

\section{Ethical approval}

This article does not contain any studies with human participants or animals performed by any of the authors

\section{References}

1. YardleyDA, Coleman R, Conte P, Cortes J, Brufsky A, Shtivelband M, Young R, Bengala C, Ali H, Eakel J, Schneeweiss A, de la Cruz-Merino L, Wilks S, O'Shaughnessy J, Gluck S, Li H, Miller J, Barton D, Harbeck N (2018) Nab-paclitaxel plus carboplatin or gemcitabine versus gemcitabine plus carboplatin as first-line treatment of patients with triple-negative metastatic breast cancer: results from the tnAcity trial. Ann Oncol 29(8):1763-1770. https:// doi.org/10.1093/annonc/mdy201

2. Schmid P, Adams S, Rugo HS, Schneeweiss A, Barrios CH, Iwata H, Dieras V, Hegg R, Im SA, Shaw Wright G, Henschel V, Molinero L, Chui SY, Funke R, Husain A, Winer EP, Loi S, Emens LA (2018) Atezolizumab and nab-paclitaxel in advanced triple-negative breast Cancer. N Engl J Med 379(22):2108-2121. https://doi.org/10.1056/NEJMoa1809615

3. Ferrero JM,Hardy-Bessard AC, Capitain O, Lortholary A, Salles B, Follana P, Herve R, Deblock M, Dauba J, Atlassi M, Largillier R (2016) Weekly paclitaxel, capecitabine, and bevacizumab with maintenance capecitabine and bevacizumab as first-line therapy for triple-negative, metastatic, or locally advanced breast cancer: results from the GINECO A-TaXel phase 2 study. Cancer 122(20):3119-3126. https://doi.org/10.1002/cncr.30170

4. Kermagoret A, Morgant G, D’ Angelo J, Tomas A, Roussel P, Bastian G, Collery P, Desmaële D (2011) Synthesis, structural characterization and biological activity against several human tumor cell lines of four rhenium(I) diseleno-ethers complexes: $\mathrm{Re}(\mathrm{CO}) 3 \mathrm{Cl}(\mathrm{PhSe}(\mathrm{CH} 2) 2 \mathrm{SePh}), \mathrm{Re}(\mathrm{CO}) 3 \mathrm{Cl}(\mathrm{PhSe}(\mathrm{CH} 2) 3 \mathrm{SePh}), \mathrm{Re}(\mathrm{CO}) 3 \mathrm{Cl}(\mathrm{HO} 2 \mathrm{C}-\mathrm{CH} 2 \mathrm{Se}(\mathrm{CH} 2) 2 \mathrm{SeCH} 2-\mathrm{CO} 2 \mathrm{H})$ and $\mathrm{Re}(\mathrm{CO}) 3 \mathrm{Cl}(\mathrm{HO} 2 \mathrm{C}-\mathrm{CH} 2 \mathrm{Se}(\mathrm{CH} 2) 3 \mathrm{SeCH} 2-\mathrm{CO} 2 \mathrm{H})$. Polyhedron 30:347-354. 
5. Collery P, Bastian G, Santoni F, Mohsen A, Wei M, Collery T, Tomas A, Desmaele D, d' Angelo J (2014) Uptake and efflux of rhenium in cells exposed to rhenium Diseleno-ether and tissue distributionof rhenium and selenium after rhenium Diseleno-ether treatment in mice. Anticancer Res 34:1679-1690

6. Collery P,Mohsen A, Kermagoret A, Corre S, Bastian G, Tomas A, Wei M, Santoni F, Guerra N, Desmaele D, d'Angelo J (2015) Antitumor activity of a rhenium (I)-diselenoether complex in experimental models of human breast cancer. Investig New Drugs 33(4):848-860. https://doi.org/10.1007/s10637-015-0265-z

7. Collery P, Santoni F, Ciccolini J, Tran TN, Mohsen A, Desmaele D (2016) Dose effect of rhenium (I)-diselenoether as anticancer drug in resistant breast tumor-bearing mice after repeated administrations. Anticancer Res 36(11):6051-6057

8. Zhang B, Fang C, Deng D, Xia L (2018) Research progress on common adverse events caused by targeted therapy for colorectal cancer. Oncol Lett 16(1):27-33. https://doi.org/10.3892/ol.2018.8651

9. Gerson JN, Ramamurthy C, Borghaei H (2018) Managing adverse effects of immunotherapy. Clin Adv Hematol Oncol 16(5):364-374 10. Marshall HT, Djamgoz MBA (2018) Immuno-oncology: emerging targets and combination therapies. Front Oncol 8(315). https://doi.org/10.3389/fonc.2018.00315

11. Mencalha A, Victorino VJ, Cecchini R, Panis C (2014) Mapping oxidative changes in breast cancer: understanding the basic to reach the clinics. Anticancer Res 34(3):1127-1140

12. AlhallakK, Rebello LG,Muldoon TJ, Quinn KP, RajaramN (2016) Optical redox ratio identifies metastatic potential-dependent changes in breast cancer cell metabolism. Biomed Opt Express 7(11): 4364-4374. https://doi.org/10.1364/BOE.7.004364

13. Bahhnassy A, Mohanad M, Shaarawy S, Ismail MF, El-Bastawisy A, Ashmawy AM, Zekri AR (2015) Transforming growth factor-beta, insulin-like growth factor I/insulin-like growth factor I receptor and vascular endothelial growth factor- a: prognostic and predictive markers in triple-negative and non-triple-negative breast cancer. Mol Med Rep 12(1):851-864.

https://doi.org/10.3892/mmr.2015.3560

14. Ho J, Lee WY, Koh KJ, Lee PP, Yan YK (2013) Rhenium(I) tricarbonyl complexes of salicylaldehyde semicarbazones: synthesis, crystal structures and cytotoxicity. J Inorg Biochem 119:10-20. https://doi.org/10.1016/j.jinorgbio.2012.10.011

15. Konkankit CC, Marker SC, Knopf KM, Wilson JJ (2018) Anticancer activity of complexes of the third row transition metals, rhenium, osmium, and iridium. Dalton Trans 47:9934-9974. https://doi.org/10.1039/c8dt01858h

16. Ramakrishna B, Nagarajaprakash R, Veena V, Sakthivel N, Manimaran B (2015) Self-assembly of oxamidato bridged ester functionalised dirhenium metallastirrups: synthesis, characterisationand cytotoxicity studies. Dalton Trans 44(40):17629-17638. https://doi.org/10.1039/c5dt02205c

17. North AJ, Hayne DJ, Schieber C, Price K, White AR, Crouch PJ, Rigopoulos A, O'Keefe GJ, Tochon-Danguy H, Scott AM, White JM, Ackermann U, Donnelly PS (2015) Toward hypoxia-selective rhenium and technetium tricarbonyl complexes. Inorg Chem 54(19):9594-9610. https://doi.org/10.1021/acs.inorgchem.5b01691

18. Kumar CA, Nagarajaprakash R, Victoria W, Veena V, Sakthivel N, Manimaran B (2016) Synthesis, characterisation and cytotoxicity studies of manganese(I) and rhenium(I) based metallacrown ethers. Inorg Chem Commun 64:39-44 
19. Parson C, Smith V, Krauss C, Banerjee HN, Reilly C, Krause JA, Wachira JM, Giri D, Winstead A, Mandal SK (2015) Anticancer properties of novel rhenium Pentylcarbanato compounds against MDA-MB-468(HTB-132) triple node negative human breast Cancer cell lines. Br J Pharm Res 4(3):362-367. https://doi.org/10.9734/BJPR/2014/4697

20. Banerjee HN, Vaughan D, Boston A, Thorne G, Payne G, Sampson J, Manglik V, Olczak P, Powell BV, Winstead A, Shaw R, Mandal SK (2018) The effects of synthesized rhenium acetylsalicylate compounds on human astrocytoma cell lines. J Cancer Sci Ther 10(2). https://doi.org/10.4172/1948-5956.1000512

21. Diaz M, Gonzalez R, Plano D, Palop JA, Sanmartin C, Encio I (2018) A diphenyldiselenide derivative induces autophagy via JNK in HTB-54 lung cancer cells. J Cell Mol Med 22(1):289-301. https://doi.org/10.1111/jcmm.13318

22. Garnica P, Encio I, Plano D, Palop JA, Sanmartin C (2018) Combined Acylselenourea-Diselenide structures: new potent and selective Antitumoral agents as autophagy activators. ACS Med Chem Lett 9(4):306-311.

https://doi.org/10.1021/acsmedchemlett.7b00482

23. Collery P (2018) Strategies for the development of selenium-based anticancer drugs. J Trace Elem Med Biol 50:498-507. https://doi.org/10.1016/j.jtemb.2018.02.024

24. Gao X, Schottker B (2017) Reduction-oxidation pathways involved in cancer development: a systematic review of literature reviews. Oncotarget 8(31):51888-51906. https://doi.org/10.18632/oncotarget.17128

25. Chen X, Song M, Zhang B, Zhang Y (2016) Reactive oxygen species regulate T cell immune response in the tumor microenvironment. Oxidative Med Cell Longev 2016:1580967-1580910.https://doi.org/10.1155/2016/1580967

26. Ohl K, Tenbrock K (2018) Reactive oxygen species as regulators of MDSC-mediated immune suppression. Front Immunol 9:2499. https://doi.org/10.3389/fimmu.2018.02499

27. Zhang Y, Han SJ, Park I, Kim I, Chay KO, Kim SM, Jang DI, Lee TH, Lee SR (2017) Redox regulation of the tumor suppressor PTEN by hydrogen peroxide and Tert-butyl Hydroperoxide. Int J Mol Sci 18(5). https://doi.org/10.3390/ijms18050982 28. Conrad M, Sandin A, Forster H, Seiler A, Frijhoff J, Dagnell M, Bornkamm GW, Radmark O, Hooft van Huijsduijnen R, Aspenstrom P, Bohmer F, Ostman A (2010) 12/15-lipoxygenase-derived lipid peroxides control receptor tyrosine kinase signaling through oxidation of protein tyrosine phosphatases. Proc Natl Acad Sci U S A 107(36):15774-15779.

https://doi.org/10.1073/pnas.1007909107

29. Garcia CV, Parrilha GL, Rodrigues BL, Teixeira SF, de Azevedo RA, Ferreira AK, Beraldo H (2016) Tricarbonylrhenium(I) complexes with 2-acetylpyridine-derived hydrazones are cytotoxic to NCI-H460 human large cell lung cancer. New J Chem 40(9): 7379-7387. https://doi.org/10.1039/C6NJ00050A

30. Kaur T, Lee WZ, Ravikanth M(2016) Rhenium(I) Tricarbonyl complexes of meso-Tetraaryl-21,23-diheteroporphyrins. Inorg Chem 55(11):5305-5311. https://doi.org/10.1021/acs.inorgchem.6b00214

31. Ruiz GT, JuliarenaMP, Lezna RO,Wolcan E, FelizMR, Ferraudi G (2007) Intercalation of fac-[(4,4' -bpy)ReI(CO)3(dppz)]+, dppz = dipyridyl[3,2-a:2' 3 '-c]phenazine, in polynucleotides. On the UVvis photophysics of the Re(I) intercalator and the redox reactions with pulse radiolysis-generated radicals. Dalton Trans (20):2020-2029. https://doi.org/10.1039/b614970g 
32. Shamelashvili KL, Shtemenko NI, Leus IV, BabIy SO, Shtemenko OV (2016) Changes in oxidative stress intensity in blood of tumorbearing rats following different modes of administration of rhenium-platinum system. Ukr Biochem J 8:29-36

33. Zeng L, Li Y, Li T, Cao W, Yi Y, Geng W, Sun Z, Xu H (2014) Selenium-platinum coordination compounds as novel anticancer drugs: selectively killing cancer cells via a reactive oxygen species (ROS)-mediated apoptosis route. Chem Asian J 9(8):2295-2302. https://doi.org/10.1002/asia.201402256

34. Su JC, Mar AC,Wu SH, Tai WT, Chu PY,Wu CY, Tseng LM, Lee TC, Chen KF, Liu CY, Chiu HC, Shiau CW (2016) Disrupting VEGF-A paracrine and autocrine loops by targeting SHP-1 suppresses triple negative breast cancer metastasis. Sci Rep 6:28888. https://doi.org/10.1038/srep28888

35. Thielemann A, Baszczuk A, Kopczynski Z, Kopczynski P, Grodecka-Gazdecka S (2013) Clinical usefulness of assessing VEGF and soluble receptors sVEGFR-1 and sVEGFR-2 in women with breast cancer. Ann Agric Environ Med 20(2):293-297

36. Nair D, Rådestad E, Khalkar P, Diaz-Argelich N, Schröder A, Klynning C, Ungerstedt J, Uhlin M, Fernandes AP (2018) Methylseleninic acid sensitizes ovarian Cancer cells to T-cell mediated killing by decreasing PDL1 and VEGF levels. Front Oncol 8(407). https://doi.org/10.3389/fonc.2018.00407

37. Ivanovic V, Demajo M, Krtolica K, Krajnovic M, Konstantinovic

M, Baltic V, Prtenjak G, Stojiljkovic B, Breberina M, Neskovic- Konstantinovic Z, Nikolic-Vukosavljevic D, Dimitrijevic B (2006) Elevated plasma TGF-beta1 levels correlate with decreased survival of metastatic breast cancer patients. Clin Chim Acta 371(12):191-193. https://doi.org/10.1016/j.cca.2006.02.027

38. Zarzynska JM (2014) Two faces of TGF-beta1 in breast cancer. Mediat Inflamm 2014:141747-141716. https://doi.org/10.1155/2014/141747

39. Kim S, Lee J, Jeon M, Nam SJ, Lee JE (2015) Elevated TGF-beta1 and -beta2 expression accelerates the epithelial to mesenchymal transition in triple-negative breast cancer cells. Cytokine 75(1): 151-158. https://doi.org/10.1016/j.cyto.2015.05.020 40. Tan AR, Alexe G, ReissM(2009) Transforming growth factor-beta signaling: emerging stem cell target in metastatic breast cancer? Breast Cancer Res Treat 115(3):453-495. https://doi.org/10.1007/s10549-008-0184-1

41. Pei Z, Li H, Guo Y, Jin Y, Lin D (2010) Sodium selenite inhibits the expression of VEGF, TGFbeta(1) and IL-6 induced by LPS in human PC3 cells via TLR4-NF-(K)B signaling blockage. Int Immunopharmacol 10(1):50-56.

https://doi.org/10.1016/j.intimp.2009.09.020

42. Santos Bernardes S, Souza-Neto FP, Pasqual Melo G, Guarnier FA, Marinello PC, Cecchini R, Cecchini AL (2016) Correlation of TGF- $\beta 1$ and oxidative stress in the blood of patients with melanoma: a clue to understanding melanoma progression? Tumor Biol 37:1-9. https://doi.org/10.1007/s13277-016-4967-4

43. Girnita L, Worrall C, Takahashi S, Seregard S, Girnita A (2014) Something old, something new and something borrowed: emerging paradigm of insulin-like growth factor type 1 receptor (IGF-1R) signaling regulation. Cell Mol Life Sci 71(13):2403-2427. https://doi.org/10.1007/s00018-013-1514-y 
44. Key TJ, Appleby PN, Reeves GK, Roddam AW(2010) Insulin-like growth factor 1 (IGF1), IGF binding protein 3 (IGFBP3), and breast cancer risk: pooled individual data analysis of 17 prospective studies. Lancet Oncol 11(6):530-542.

https://doi.org/10.1016/s1470-2045(10)70095-4

45. Peyrat JP, Bonneterre J, Hecquet B, Vennin P, Louchez MM, Fournier C, Lefebvre J, Demaille A (1993) Plasma insulin-like growth factor-1 (IGF-1) concentrations in human breast cancer. Eur J Cancer 29a(4):492-497

46. Bartucci M, Morelli C, Mauro L, Ando S, Surmacz E (2001) Differential insulin-like growth factor I receptor signaling and function in estrogen receptor (ER)-positive MCF-7 and ERnegative MDA-MB-231 breast cancer cells. Cancer Res 61(18):67476754.

47. Zhou Y, Li S, Li J,Wang D, Li Q (2017) Effect of microRNA-135a on cell proliferation, migration, invasion, apoptosis and tumor angiogenesis through the IGF-1/PI3K/Akt signaling pathway in nonsmall cell lung Cancer. Cell Physiol Biochem 42(4):1431 1446. https://doi.org/10.1159/000479207

48. Fu YF, Liu X, Gao M, Zhang YN, Liu J (2017) Endoplasmic reticulum stress induces autophagy and apoptosis while inhibiting proliferation and drug resistance in multiple myeloma through the

PI3K/Akt/mTOR signaling pathway. Oncotarget 8(37):61093-61106. https://doi.org/10.18632/oncotarget.17862

49. Bibollet-Bahena O, Almazan G (2009) IGF-1-stimulated protein synthesis in oligodendrocyte progenitors requires PI3K/mTOR/ Akt and MEK/ERK pathways. J Neurochem 109(5):1440-1451.https://doi.org/10.1111/j.1471-4159.2009.06071.x

50. Ren G, Ali T, Chen W, Han D, Zhang L, Gu X, Zhang S, Ding L, Fanning S, Han B (2016) The role of selenium in insulin-like growth factor I receptor (IGF-IR) expression and regulation of apoptosis in mouse osteoblasts. Chemosphere 144:2158-2164. https://doi.org/10.1016/j.chemosphere.2015.11.003 
Fig. 1 The rhenium(I)- diselenoether (Re-diSe) and the bidentate diselenoether ligand (di-Se)

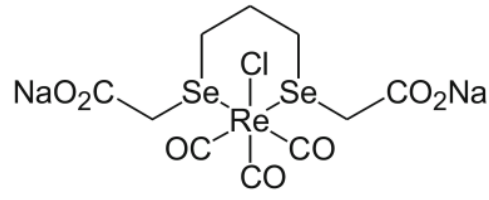

Re-diSe<smiles>O=C(O)C[Se]CCC[Se]CC(=O)O</smiles>

Diselenium ligand

Fig. 2 Dose-effect of Re-diSe on different cancer cell lines and one normal HEK-293 cell line, after an exposure time of $72 \mathrm{~h}$. The graph represents the $\%$ of inhibition of the cells (mean of triplicate experiments). MDA-MB231: hormone-independent breast cancer cell line. MCF-7: hormone-dependent breast cancer cell line. PC-3: prostate cancer cell line. HT-29: colon cancer cell line. HeLa: uterine cancer cell line. A-549: lung cancer cell line. HEK-293: human kidney embryonic cell line

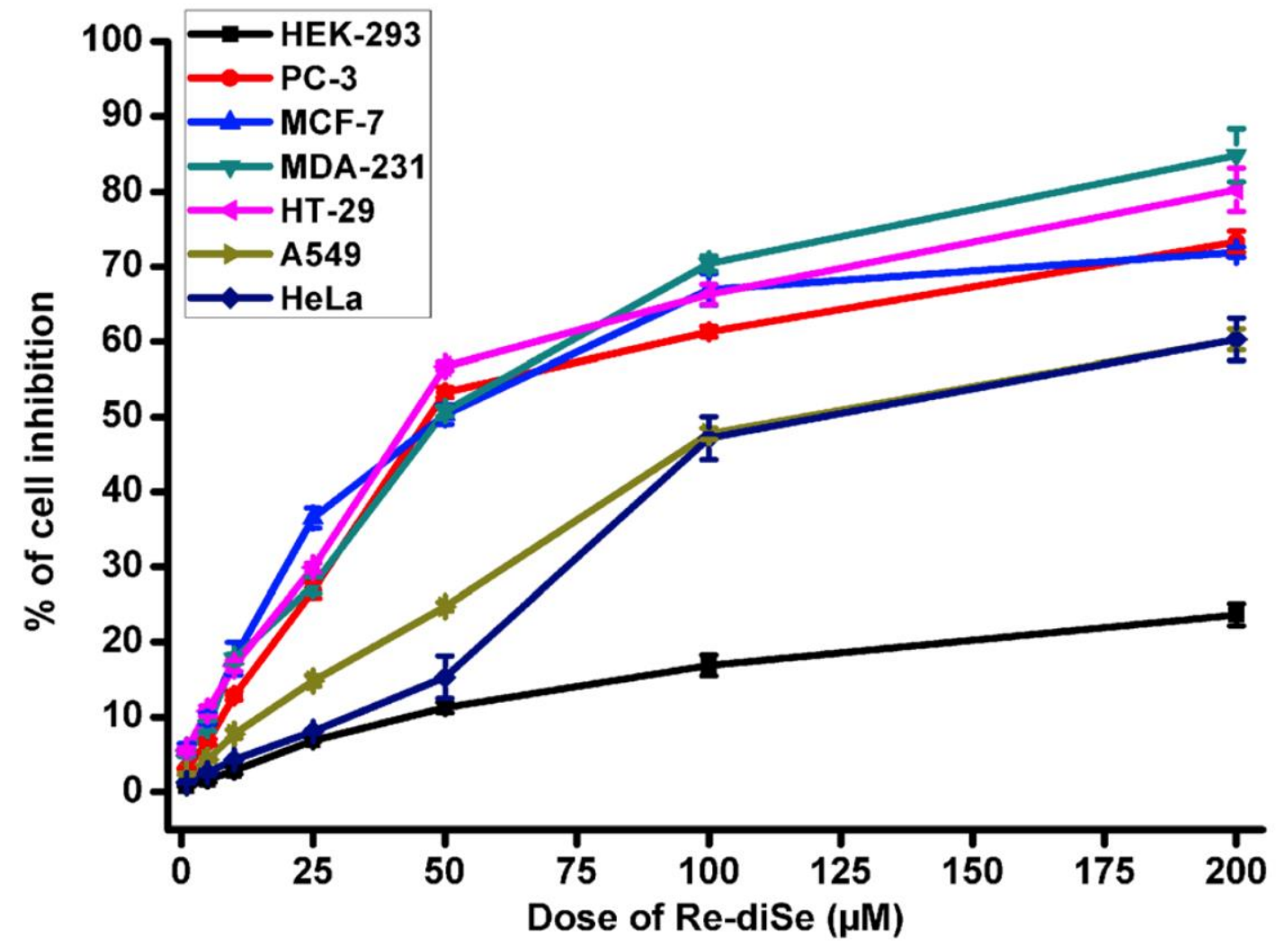


Fig. 3 Inhibitory effects of Re-diSe and di-Se compounds after $72 \mathrm{~h}$ and $120 \mathrm{~h}$ exposure time

a) exposure time $72 \mathrm{~h}$ with Re-diSe
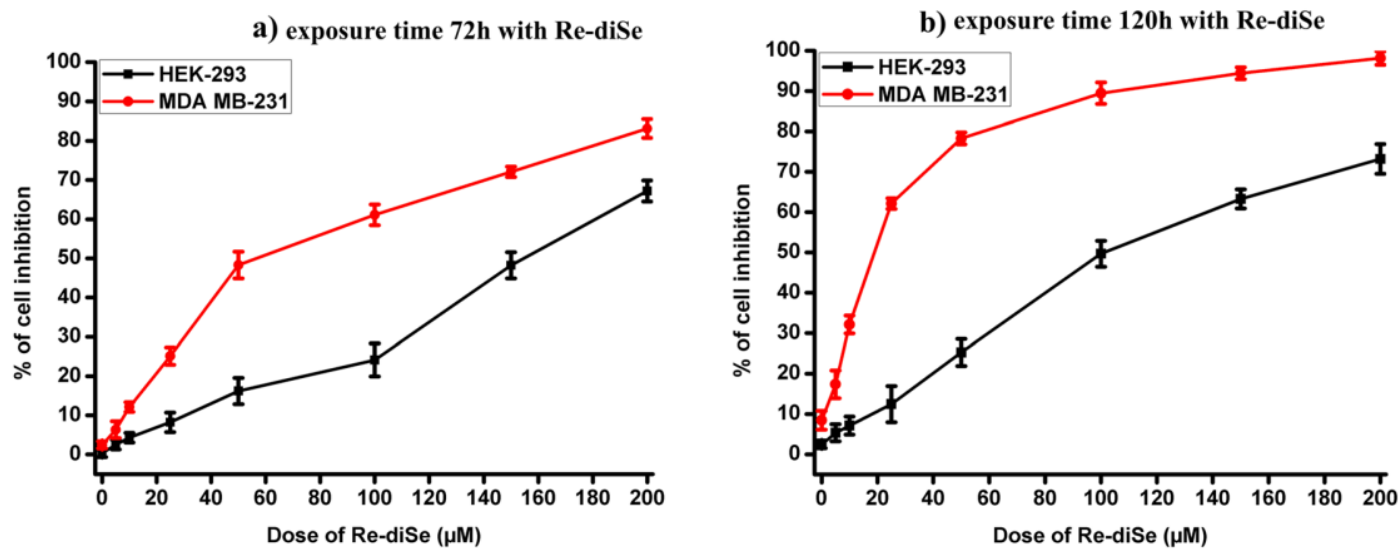

c) exposure time $72 \mathrm{~h}$ with di-Se

d) exposure time $120 \mathrm{~h}$ with di-Se
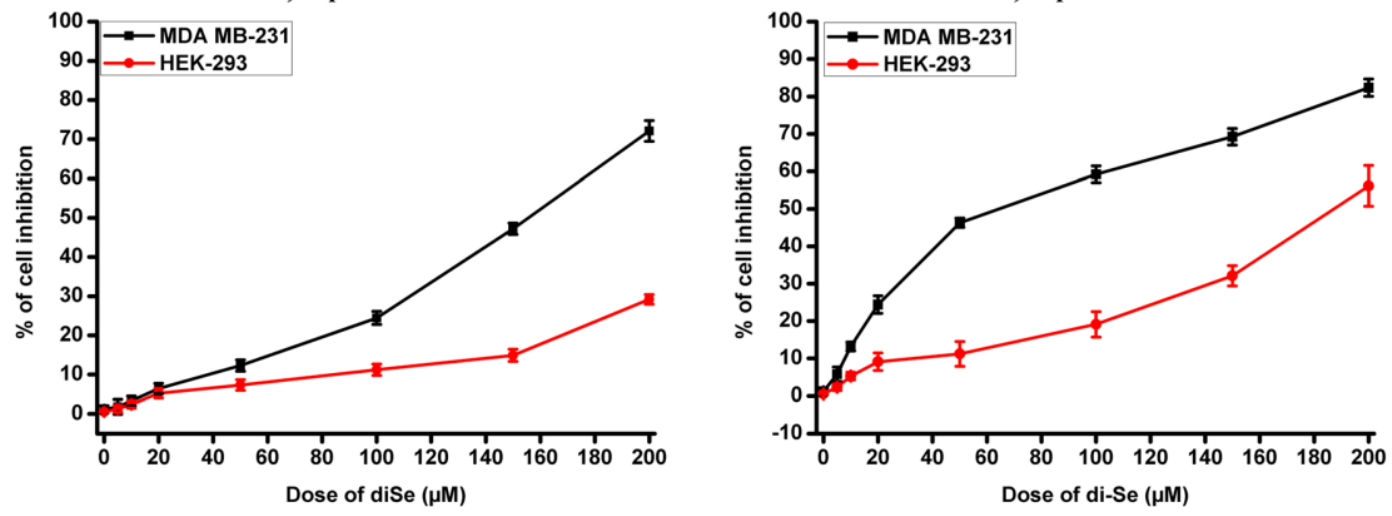


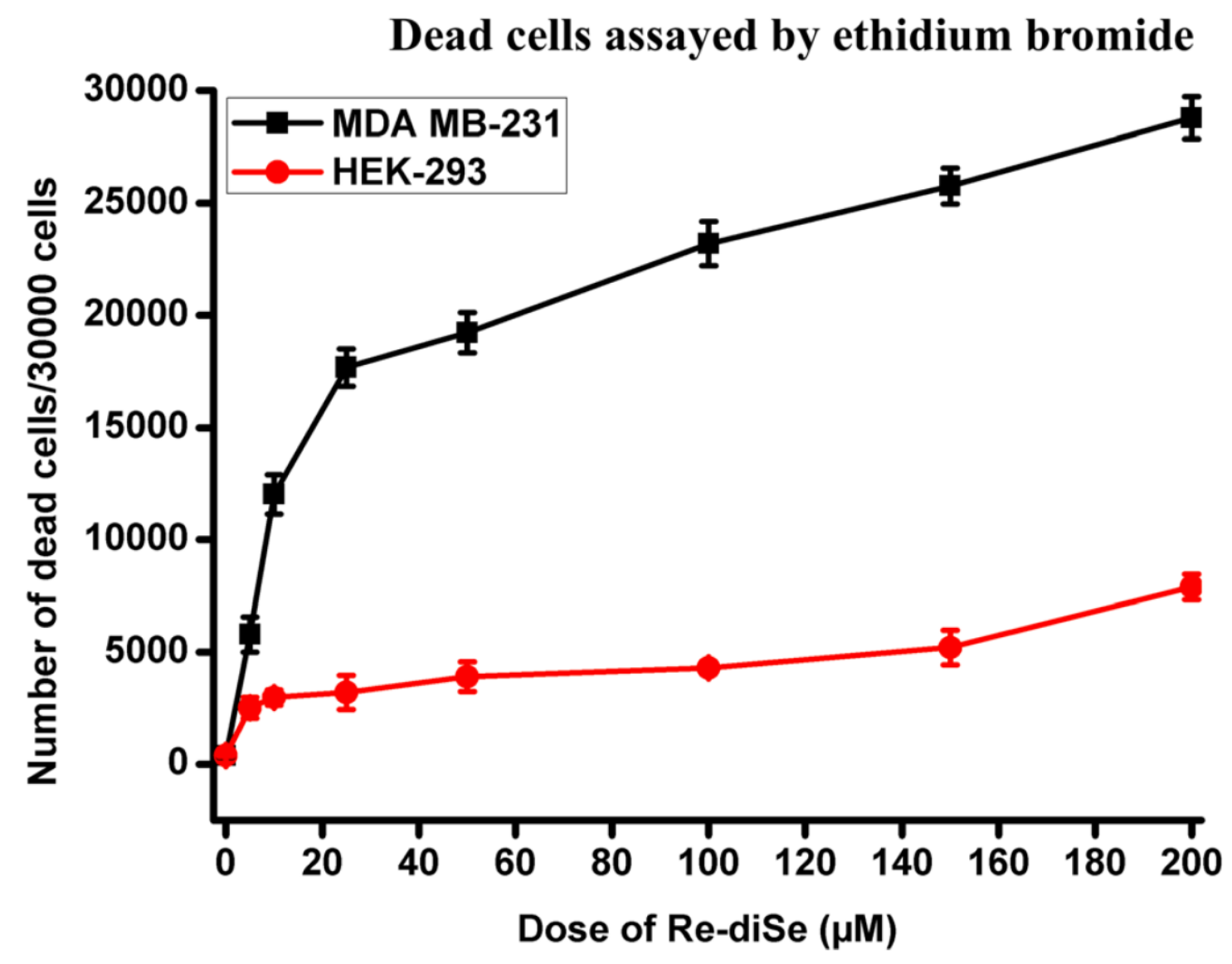




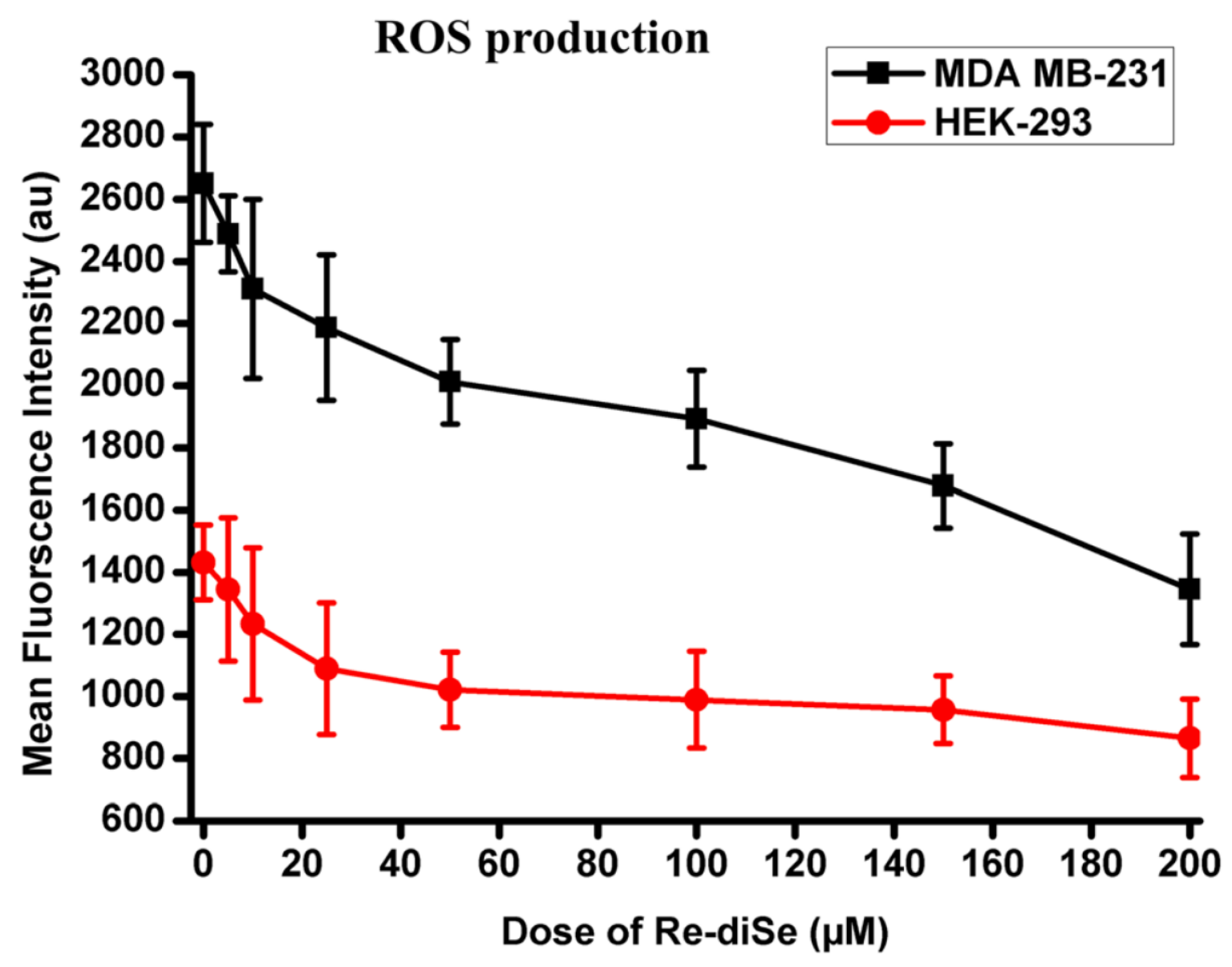


Fig. 6 Dose-effect of Re-diSe on VEGF-A levels in the cell culture medium after exposure of the MDA-MB231 cancer cells and the HEK- 293 normal cells for $120 \mathrm{~h}$. Results were statistically significant even with doses $\geq 5 \mu \mathrm{M}$ in the medium of cancer cells, but no significant decrease was observed in the medium of the normal cells

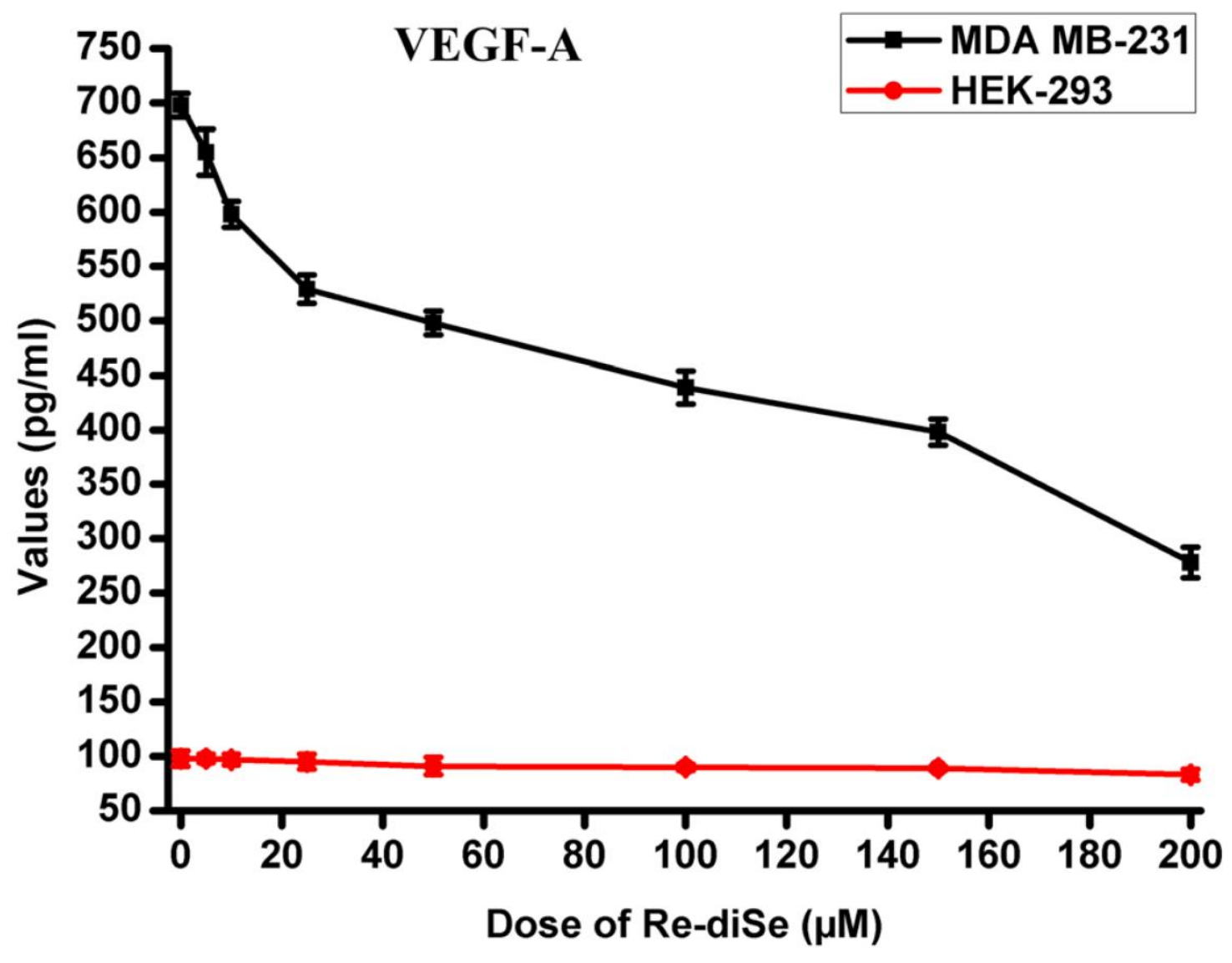


Fig. 7 Dose-effect of Re-diSe on TGF- $\beta 1$ levels in the cell culture medium after exposure of the MDA-MB231 cancer cells and the HEK- 293 normal cells for $120 \mathrm{~h}$. Results were statistically significant even with doses $\geq 5 \mu \mathrm{M} \mu \mathrm{M}$ in the medium of cancer cells, but no significant decrease was observed in the medium of the normal cells

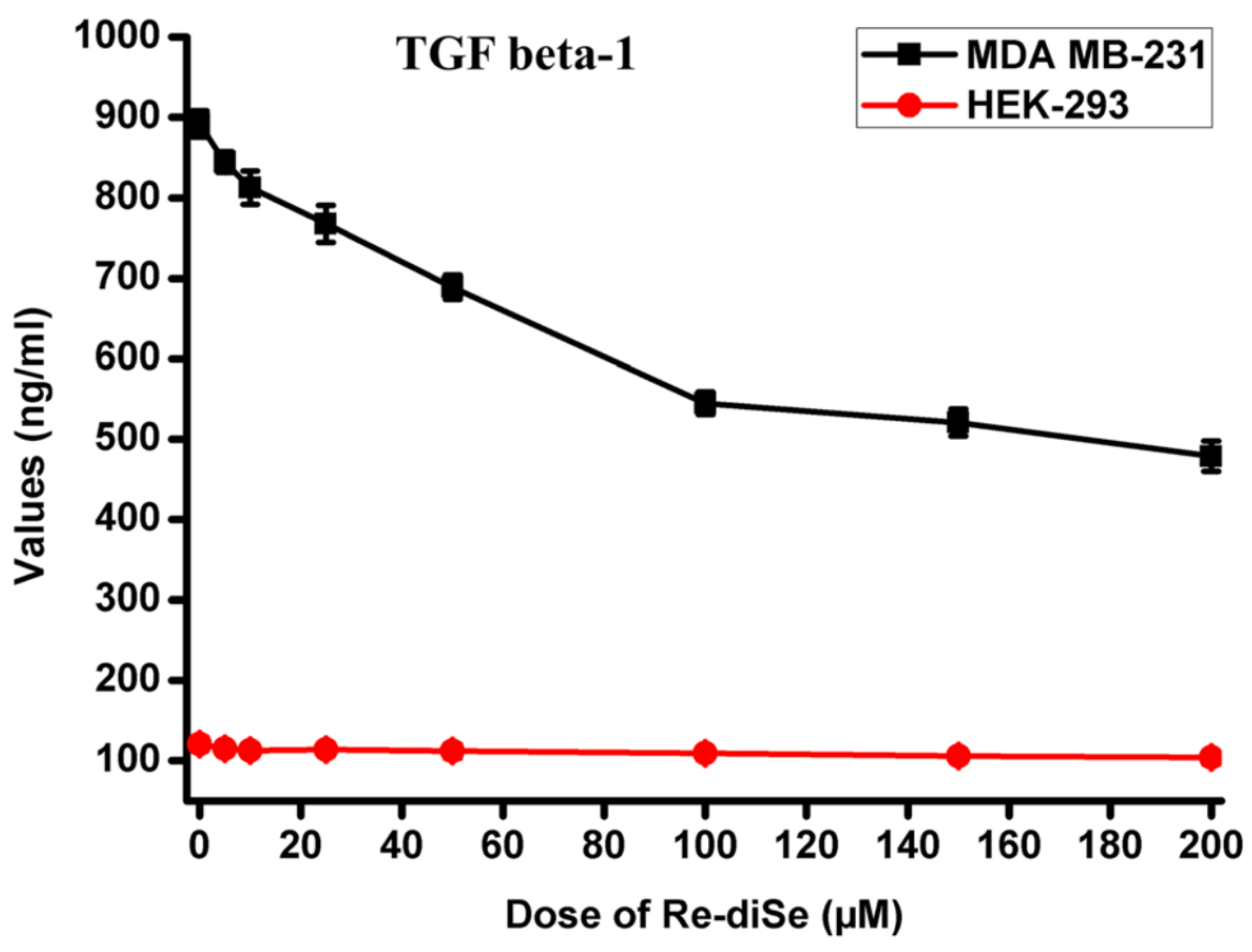


Fig. 8 Dose-effect of Re-diSe on IGF-1 levels in the cell culture medium after exposure of theMDA-MB231 cancer cells and the HEK-293 normal cells for $120 \mathrm{~h}$. Results were significant with doses $\geq 5 \mu \mathrm{M}$ Re-diSe with the cancer cells but the decrease was not significant for the normal cells

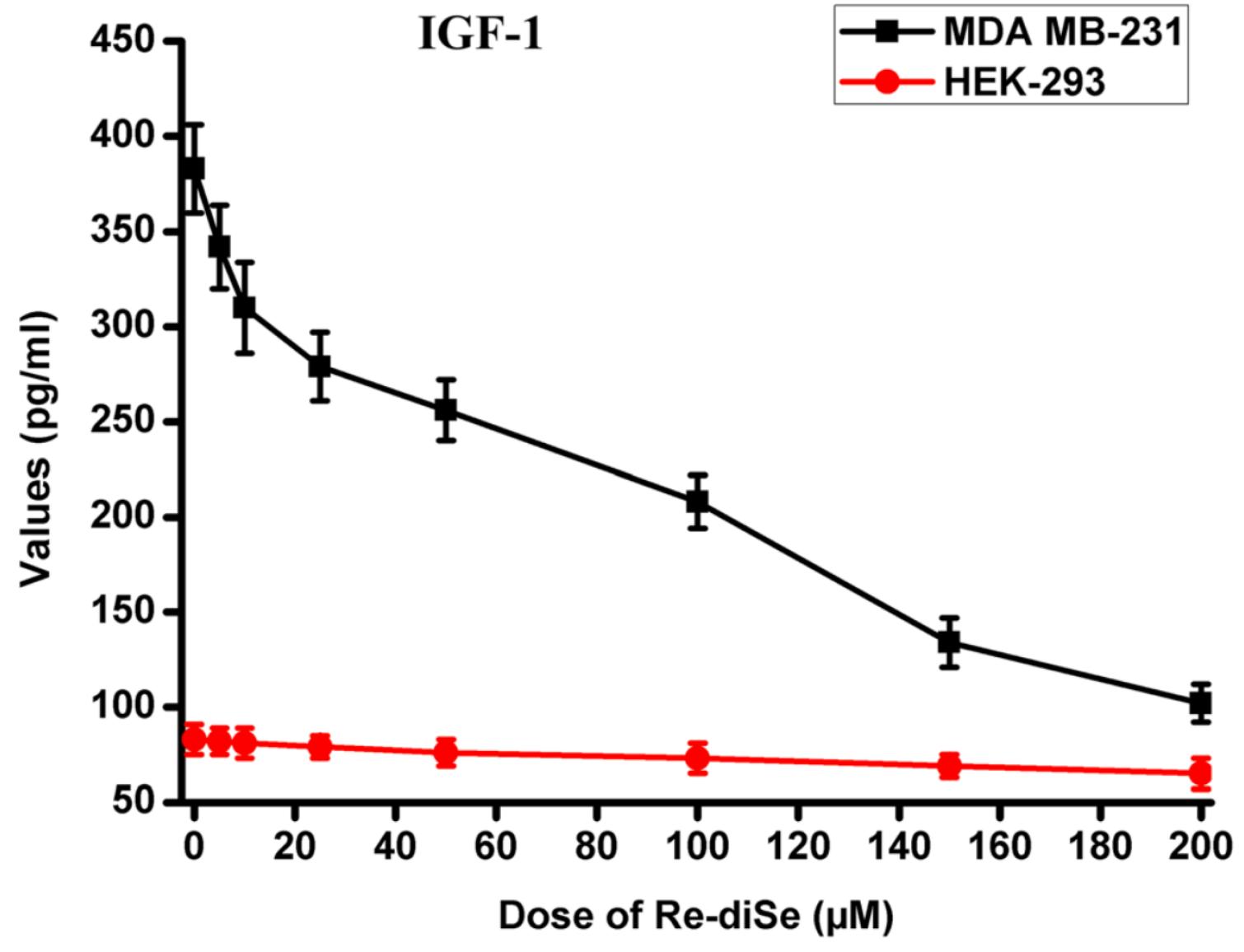

